\title{
Learning at Home and Abroad: How Competition Conditions the Diffusion of Party Strategies
}

\author{
Sebastian Juhl1* (D) and Laron K. Williams ${ }^{2}$ \\ ${ }^{1}$ Collaborative Research Center 884, University of Mannheim, Germany and ${ }^{2}$ Department of Political Science, University of \\ Missouri, Columbia, MO, USA \\ ${ }^{\star}$ Corresponding author. E-mail: sebastian.juhl@gess.uni-mannheim.de
}

(Received 26 May 2020; revised 15 September 2020; accepted 4 November 2020; first published online 18 February 2021)

How do parties decide when to campaign on valence issues given high degrees of uncertainty? Although past studies have provided evidence of transnational emulation of parties' position-taking strategies, these findings do not directly apply to saliency strategies. Moreover, the exact diffusion mechanism remains largely elusive. Based on the issue saliency literature, this study develops novel theoretical propositions and argues that conscious learning enables parties to infer the relative utility of emphasizing consensual issues during an electoral campaign. The proposed theory gives rise to different expectations at the domestic and transnational levels because of the distinct logic of issue competition. By analyzing environmental issue emphasis in party manifestos, the authors find direct transnational dependencies and indirect spillover effects among the parties' saliency strategies. They identify conscious learning, rather than mere imitation or independent decision making, as the diffusion mechanism at work. Yet, in line with saliency-based theories, electoral competition mutes the diffusion of electoral strategies domestically.

Keywords: valence; issue competition; party manifestos; diffusion; learning

Uncertainty is a pervasive feature of democratic elections. When crafting their manifestos, parties lack the information necessary to unambiguously identify an optimal vote-maximizing strategy (Laver and Sergenti 2012; Somer-Topcu 2009; Budge 1994). To mitigate this problem, parties can utilize information on the past electoral performance of other parties both within and outside their domestic party system. Numerous studies on policy diffusion empirically demonstrate that parties rely on such heuristics and emulate each other's position-taking strategies (for example, Berry and Baybeck 2005; Böhmelt et al. 2016; Böhmelt et al. 2017; Butler et al. 2017; Ezrow et al. 2019; Gilardi 2010; Volden, Ting and Carpenter 2008).

Yet these studies are confined to positional issues, on which parties attempt to distinguish their ideological profile - typically on a left-right dimension - from that of their competitors. Consequently, the extent to which the findings are generalizable to consensual (so-called valence) issues (Stokes 1963, 373) remains largely unknown as they do not fit the logic of the Downsian model of party competition. In addition, the literature is inconclusive regarding the precise mechanism underlying the diffusion process. Empirical research has yet to develop strategies that enable researchers to differentiate conscious learning from mere imitation or even independent decision making (Graham, Shipan and Volden 2013; Shipan and Volden 2008; Volden, Ting and Carpenter 2008).

Against this background, the present study explores how parties decide on the optimal issue saliency strategy in an electoral campaign. We combine insights from saliency-based theories of party competition (for example, Budge and Farlie 1983; Petrocik 1996; Robertson 1976) 
and the agenda-setting literature (for example, Green-Pedersen and Mortensen 2010; Green-Pedersen and Mortensen 2015) with models of learning and intergovernmental policy diffusion (for example, Dolowitz and Marsh 2000; Gilardi 2010; Volden, Ting and Carpenter 2008) to develop a theory that identifies transnational learning as a mechanism to mitigate electoral uncertainty. Parties do not decide on a strategy in isolation: they draw on their own history of strategic decisions and observe other parties' electoral fortunes. These sources of information help parties gauge the relative benefit of emphasizing valence issues.

Importantly, since the logic of party competition differs between positional and valence issues, our theory offers novel predictions about parties' ability to learn from other parties domestically. In contrast to position-taking strategies, we argue that competition prevents parties from learning about the optimal saliency strategy from their domestic competitors. However, since parties do not compete transnationally, our theory expects parties to learn from other parties across national borders.

Our empirical analysis is based on party manifestos from twenty-five EU countries ${ }^{1}$ in the period from 1975 to 2015. We focus on the parties' emphasis on the environment - an issue with a high valence component and a niche party as the unequivocal issue owner (Spoon, Hobolt and de Vries 2014). The analysis provides evidence that parties systematically learn from saliency strategies adopted by successful foreign family members, creating interdependencies among European party systems. Our research strategy also enables us to show that conscious learning, instead of mere imitation or the independent adaptation of similar strategies, is responsible for the observable transnational diffusion process - a distinction that poses severe difficulties for empirical analyses (Butler et al. 2017; Gilardi 2010; Shipan and Volden 2008).

At the domestic level, however, we find that competition impedes learning. Here, parties are not affected by the valence strategies of their domestic competitors, and only the electoral success of the issue owner exerts a non-linear effect on mainstream parties' saliency strategies. Due to the learning mechanism identified here, this effect of the domestic issue owner indirectly alters the saliency strategies of parties across the borders as well.

The study contributes to the literatures on party competition and policy diffusion in at least two decisive ways. First, we extend the argument about the transnational diffusion of parties' position-taking strategies presented elsewhere (for example, Böhmelt et al. 2016; Böhmelt et al. 2017) to saliency strategies. Due to the distinct logic of issue competition, we identify different diffusion patterns for valence issues as compared to positional issues. Secondly, we demonstrate that the mechanism underlying the diffusion process is conscious learning. While previous research struggled to differentiate learning from imitation, or even similar but independent policy choices, our empirical strategy enables us to demonstrate that only conscious learning by strategic parties is supported by the data.

\section{When do Parties Emphasize Valence Issues?}

Prior to an election, parties attempt to attract voters by formulating policy proposals in their manifestos. In doing so, they single out a number of issues that are most rewarding in terms of votes and allocate the scarce space within their manifestos to these issues, given the other parties' strategies (Laver and Garry 2000). This process, however, is dramatically complicated by the fact that parties act in a low-information environment in which uncertainty is ubiquitous. As they do not know whether clearly pronouncing their position on conflictual issues or campaigning on valence issues will attract the most votes, allocating manifesto space to issues is a difficult task. Even polls cannot provide the necessary information since they do not identify why citizens vote as they do (for example, Budge 1994; Somer-Topcu 2009).

Below, we elaborate on the parties' repertoire of electoral strategies, differentiate between position-taking and saliency strategies, and derive novel expectations about the diffusion of

${ }^{1}$ The analysis includes all EU member states except Croatia, Malta and Romania. 
party strategies within and beyond the boundaries of national political systems. While we theorize that the transnational diffusion of saliency strategies follows similar patterns as the diffusion of position-taking strategies, we expect to find differences at the domestic level that are caused by the distinct ways in which parties compete on conflictual and consensual issues as well as the informational content of other parties' strategic choices.

\section{Parties' Position-Taking and Saliency Strategies}

In an influential article, Stokes (1963) points to several shortcomings of the dominant spatial model of party competition proposed by Downs (1957). Most notably, he outlines the importance of valence issues for party competition. In contrast to positional issues, valence issues are characterized by a consensus of the goal of any policy within the electorate. Since the preferences of parties and voters are not distributed over a finite set of policy alternatives but converge at a single position, these issues do not fit the logic of the Downsian model (Curini and Martelli 2015; Green 2007; Stokes 1963). Instead of choosing a party based on ideological proximity, voters evaluate parties based on their competence with respect to the issue. The party that the electorate perceives to be the most competent wins the election.

In an electoral campaign, parties can either invest their resources in an attempt to attract votes based on their ideological stances, or they can decide to campaign on consensual policies and socially shared values by emphasizing valence issues (for example, Ceron and Curini 2016; Green 2007). ${ }^{2}$ However, the differentiation between positional and valence issues has profound implications for the electoral strategies parties employ.

Position-taking strategies directly emerge from the Downsian model and are based on the premise that voters will choose the party closest to their most preferred policy position in a latent policy space that is assumed to be low dimensional and static. By explicitly stressing their policy platform on conflictual issues, parties attempt to occupy the vote-maximizing position - conditional on their competitors' locations - and communicate their policy preferences to the electorate. Consequently, these strategies are concerned with identifying and occupying an optimal policy position.

By contrast, valence issues are characterized by an almost unanimous agreement among the electorate about the most preferred policy. As a result, parties cannot rely on their repertoire of position-taking strategies to maximize their respective vote share. Instead, they need to single out the issues on which they are perceived to be the most competent. Therefore, parties' saliency strategies concentrate on selectively emphasizing advantageous issues on which the voters perceive them to be the most competent (for example, Budge 2015). A party that is able to increase the saliency of issues on which it has a good reputation in the electorate will fare better in an electoral contest.

In general, parties face different kinds of uncertainty regarding the identification of an optimal electoral strategy. Regarding confrontational issues on which voters' preferences are distributed over the policy space, parties lack accurate information on the precise preference configuration in the electorate and the other parties' policy stances (for example, Ezrow et al. 2019). With respect to consensual issues, the uncertainty parties face stems from the lack of information about voters' assessments of the parties' competence on each issue. These differences have important implications for the parties' ability to use the other parties' decisions as heuristics in order to mitigate the uncertainty. For confrontational issues, the strategic choices of rival parties reveal valuable information that improve a party's ability to determine its optimal positiontaking strategy. For valence issues, however, the information revealed by competing parties' decisions does not help a party to infer its relative competence, or reveal which party is perceived to be the most competent on other issues relevant in an electoral contest.

\footnotetext{
${ }^{2}$ As Stokes $(1963,373)$ notes, there is no a priori classification of issues as either positional or valence. Rather, the distinction needs to be justified on empirical grounds.
} 


\section{Transnational Learning in the European Multilevel System}

In their search for information, parties can rely on information from the outside of the party system they act in. Based on these additional pieces of information, parties are able to develop heuristics, broadly defined as a 'decision-making rule of thumb that can in practice be very effective' (Laver and Sergenti 2012, 25). In a nutshell, heuristics are cognitive shortcuts that enable parties to identify and select the most promising strategy from a set of feasible strategies. Depending on their electoral performance, other parties can serve as role models for electoral success. Thereby, parties might adopt electoral strategies that have been proven to be successful elsewhere.

The literature on policy diffusion provides convincing evidence of diffusion processes across national borders (for example, Berry and Baybeck 2005; Butler et al. 2017; Gilardi 2010; Volden, Ting and Carpenter 2008). In their analysis, Böhmelt et al. (2016) investigate transnational interdependencies in parties' position-taking strategies (see also Böhmelt et al. 2017; Ezrow et al. 2019). In line with previous research (for example, Laver and Sergenti 2012; Somer-Topcu 2009), the authors argue that electoral uncertainty crucially limits parties' ability to decide on a vote-maximizing position before an election. Since they are unable to easily identify an optimal policy position, parties emulate the positional strategies of foreign parties that successfully obtained governmental offices. As Ezrow et al. (2019) show, this emulation is rewarding electorally as it helps parties identify the position of the domestic median voter.

Although these studies solely examine transnational diffusion processes with respect to the parties' position-taking strategies, there is no reason to believe that the mechanism is limited to positional issues. Indeed, parties might use similar heuristics to decide whether prioritizing valence issues in their manifestos pays off on Election Day. In this regard, parties have information about the other parties' saliency strategies and electoral performance, which helps them evaluate the prospective benefit of emphasizing valence issues. Hence, we expect to find similar transnational diffusion patterns for position-taking and saliency strategies.

Prior studies have not identified the exact underlying mechanism that causes party strategies to diffuse transnationally (Volden, Ting and Carpenter 2008). While several different mechanisms might underlie transnational diffusion processes, the mechanism of key interest in many of these studies is conscious learning. ${ }^{3}$ Berry and Baybeck present the following general definition of learning: 'When confronted with a problem, decision makers simplify the task of finding a solution by choosing an alternative that has proven successful elsewhere' $(2005,505)$. Empirically showing that learning is the underlying diffusion mechanism, however, remains an elusive task since it requires researchers to measure success. This challenge leads Volden, Ting and Carpenter to conclude that, 'despite decades of study, systematic evidence that governments learn from one another has been limited' (2008, 319). Assuming that parties instrumentally seek to gain votes, this limitation is less severe in the context of electoral competition since success can be quantified by the party's change in vote share between two consecutive elections (Graham, Shipan and Volden 2013).

Clearly, not every successful party is equally likely to serve as a role model for all other parties. It seems unreasonable to expect that, for example, the Swedish Social Democratic Party (SAP) learns about successful strategies from a regionalist party in another party system like the Republican Left of Catalonia (ERC) in Spain, or vice versa. By examining who becomes a potential role model for other actors, Gilardi (2010) illustrates the conditional nature of learning processes. He shows that ideological similarity facilitates the transfer of information and policies among the entities. Parties are more responsive to the experiences of ideologically similar parties, which makes them more likely to adopt saliency strategies that are similar to the strategies of successful members of their own party family (Butler et al. 2017; Green-Pedersen and Mortensen 2015).

\footnotetext{
${ }^{3}$ The diffusion mechanisms primarily discussed are learning, (economic) competition, imitation (also referred to as emulation or socialization) and coercion. For a comprehensive discussion of these processes, see Graham, Shipan and Volden (2013) and Shipan and Volden (2008).
} 
Another distinction that affects a party's learning behavior is the one between mainstream and niche parties. Niche parties are characterized by their selective and exclusive focus on issues that were previously outside the political discourse and are unaligned with the dominant party positions (Meguid 2005, 347f). While mainstream parties are more responsive to other parties' issue agendas, niche parties are less affected by the other parties' behaviors. Learning is therefore more likely to occur among established mainstream parties than among niche parties (Green-Pedersen and Mortensen 2015). Referring to the example above, it is therefore reasonable to expect the Swedish SAP to learn, for example, from the German Social Democratic Party (SPD) while the Spanish ERC, given their niche party character, is unlikely to take cues from other parties.

In principle, learning from other parties can occur in two ways. First, parties can learn from the successes of other parties and simply copy the strategies of those that have proven successful. Second, other parties' failures can provide valuable information about the likely consequences of a strategic choice with respect to valence issues (for example, Dolowitz and Marsh 1996, 351). If a party performed poorly in the last election, other parties will be less inclined to adopt similar strategies. Following this line of argumentation, the first hypotheses are:

Hypothesis 1a (Foreign Winner Hypothesis): Parties emphasize valence issues when parties from the same party family in other countries were successful with this strategy.

Hypothesis $1 \mathrm{~b}$ (Foreign Loser Hypothesis): Parties de-emphasize valence issues when parties from the same party family in other countries were unsuccessful with emphasizing these issues.

It is important to note that, without further assumptions, this line of reasoning does not imply that parties in European party systems will ultimately converge to a stable long-run equilibrium of issue emphasis. For this to occur, voters' demand for such issues would have to remain stable over time. If, instead, voters' demands for certain policy issues vary over time, a party learning from another party that was successful in an election three years ago might not be successful in the future due to changes in the demand side. As a result, other parties will turn to the strategies adopted by alternative parties that have been successful, which implies that no convergence takes place because the underlying demand has changed. Hence, our argument does not suggest a convergence to a long-run equilibrium of issue emphasis.

So far, we expect similar transnational diffusion patterns for position-taking and saliency strategies. Yet unlike Böhmelt et al. (2016), who conclude that parties merely emulate each other's strategies, we expect parties to condition their learning behavior on the observed outcome. If a strategy was electorally rewarding, it will be adopted elsewhere. Otherwise, similar parties in other polities will turn away from strategies that were unsuccessful elsewhere.

\section{Domestic Issue Competition and the Party System Agenda}

Domestic factors are indisputably crucial to understanding parties' saliency strategies. While prior studies have identified numerous factors that may affect parties' saliency profiles, we argue that the structure of domestic party competition conditions their ability to learn from one another (Berry and Baybeck 2005). Moreover, since parties compete differently on conflictual and consensual issues, we predict that the diffusion of saliency strategies is distinct from the process governing the diffusion of position-taking strategies.

Since Robertson (1976), the idea that parties primarily compete by focusing on different issues rather than engaging in direct opposition during a campaign has been well established; it has led to the development of several saliency-based theories of party competition. ${ }^{4}$ These theories have increasingly gained importance as empirical studies have provided evidence of the prominence of

\footnotetext{
${ }^{4}$ Theories focusing on issue saliency come in many slightly different forms, including saliency theory (e.g., Budge and Farlie 1983; Robertson 1976), issue ownership theory (e.g., Petrocik 1996) and the agenda-setting literature (e.g.,
} 
valence issues in Western European countries (for example, Elias, Szöcsik and Zuber 2015; Green-Pedersen 2007; Spoon, Hobolt and de Vries 2014).

Issue competition is understood as parties' struggle over which issues dominate the political agenda (Carmines and Stimson 1993). In line with the saliency theory developed by Budge and Farlie (1983) and the issue ownership theory (Petrocik 1996), parties talk about issues they want to put on the political agenda. Their electoral campaigns are designed to selectively emphasize issues on which the electorate perceives them to be the most competent, since these issues will benefit the party that 'owns' them on Election Day. At the same time, parties simply ignore all other issues that might benefit their competitors (Budge and Farlie 1983; Petrocik 1996; Robertson 1976).

Importantly, the selective emphasis hypothesis directly counteracts parties' learning efforts at the domestic level. If a party successfully uses an issue to mobilize the electorate, competition among domestic parties prevents its competitors from copying this strategy, irrespective of a shared party family affiliation. Instead, the other parties will try to avoid this issue because increasing its saliency will only be beneficial to the party that owns it (Budge and Farlie 1983; Riker 1996; Robertson 1976). Hence, in stark contrast to position-taking strategies, we argue that competition impedes learning at the domestic level.

Hypothesis 2 (Party Competition Hypothesis): Parties' emphasis on valence issues is not affected by their domestic competitors' strategies.

Yet numerous studies find a substantial proportion of issue convergence in the parties' campaigns (for example, Dolezal et al. 2014; Green-Pedersen 2007; Spoon, Hobolt and de Vries 2014). In an attempt to reconcile this observation with the idea of party competition by selective issue emphasis, Green-Pedersen and Mortensen (2010) propose an agenda-setting model of issue competition. They argue that a party's issue attention is not only determined by party-specific characteristics, like preferences and issue ownership. Parties also need to consider the broader 'party system agenda' (Green-Pedersen and Mortensen 2010, 260), which is the sum of all issues relevant in an electoral contest. While parties try to promote issues favorable to them, they simultaneously have to respond to an agenda that is largely beyond their immediate control. The riding the wave theory (for example, Ansolabehere and Iyengar 1994; Klüver and Sagarzazu 2016; Spoon and Klüver 2015) argues that parties have incentives to emphasize timely issues that are salient to the electorate, which forces them to address issues owned by other parties. While parties wish to solely address issues favorable to them, external factors cause them to consider other issues during their campaigns as well.

Taken together, electoral competition has a distinct effect on parties' ability to learn about the most successful strategy from other parties in their party system. Since competitors' electoral fortunes can reveal valuable information about the policy preferences of the electorate, parties can use this heuristic to identify the most promising position-taking strategy. Several studies provide empirical evidence of these dependencies of position-taking strategies (for example, Adams and Somer-Topcu 2009; Böhmelt et al. 2016; Williams 2015; Williams and Whitten 2015). At the same time, our theory predicts that the saliency strategies employed by rival parties have no heuristical value. Observing other parties' decisions does not provide any guidance on the optimal saliency strategy as it does not allow parties to infer the voters' assessment of the relative competence of parties in a particular policy area.

\section{Green Parties and the Environment}

In order to study parties' learning behavior with respect to valence issues, the present study focuses on the parties' emphasis on environmental issues in their manifestos. At least three circumstances make this issue especially interesting in this context.

Green-Pedersen and Mortensen 2010; Riker 1996). Since they share similar core predictions about how party competition is structured, we jointly refer to these theories as saliency-based theories (Budge 2015; Green and Hobolt 2008). 
First and foremost, the environment is recognized as an issue with a high valence component (Abou-Chadi 2016; Carter 2013; Dolezal et al. 2014; Spoon, Hobolt and de Vries 2014). There is overwhelming agreement among the electorate about the desire for environmental protection. Although some parties have adopted a more critical stance on policies that foster environmental protection, they are highly unlikely to actively demand an increase in air pollution or environmental damage in their manifestos (Carter 2013, 76). These parties instead ignore the issue altogether. Alternatively, Lowe et al. (2011) show that parties that oppose protective environmental policies might also employ more nuanced strategies: they highlight the cost of these measures by contrasting environmental protection with economic prosperity. In general, while not all parties take a pro-environmental stance, they avoid campaigning in favor of environmental destruction and either ignore the issue or frame it as contrasting priorities.

Secondly, environmental issues arose at roughly the same time on the political agendas of almost all European countries. In the mid-1970s and early 1980s, green parties emerged all across Europe. They politicized environmental issues and placed them on the political agenda, which had implications for the other parties' strategies and the structure of party competition (Carter 2013). As the politicization of environmental issues took place at approximately the same time in European party systems, it is feasible to compare the parties' adaptation to the new issue and the resulting transformation of the political conflict within the respective party systems across countries.

Thirdly, green parties are the unequivocal and easily recognizable owner of environmental issues (for example, Abou-Chadi 2016; Wagner and Meyer 2014). While it can be challenging to identify the owner of other valence issues - like corruption (for example, Ceron and Curini 2016; Curini and Martelli 2015) - across different national contexts, environmental issues are the defining feature of green parties. In line with this expectation, Spoon, Hobolt and de Vries $(2014,366)$ report a strong and spontaneous association between environmental issues and green parties among the electorate. It is easy for parties and voters to identify the party that benefits from an increase in the issue's saliency during a campaign in a given party system. Thus the emergence and successes of green issue owners in European party systems forces the other parties to develop strategies to deal with the new issue and their new competitor.

Of course, environmental concerns such as air pollution and climate change are not countryspecific but supranational challenges (Spoon, Hobolt and de Vries 2014, 364). On the one hand, this similarity makes parties more likely to attempt to learn from the experiences of other parties (for example, Dolowitz and Marsh 1996). They recognize that other parties have already addressed the problem of whether to emphasize the valence issue or to campaign on conflictual issues instead, which allows them to draw lessons from other parties' behaviors. On the other hand, common exposure to an external shock might lead parties to adopt similar strategies completely independently from one another. Our research design must therefore overcome the considerable challenge of empirically disentangling learning from independent decision making in this context (for example, Volden, Ting and Carpenter 2008).

\section{Research Strategy}

\section{Case Selection and Dependent Variable}

Our sample consists of all EU countries except Croatia, Malta and Romania. The countries' similarities and the formalized realm of the EU makes it an ideal setting in which parties can learn from foreign parties (for example, Hix and Høyland 2013). In order to study parties' learning behaviors, we exclude green parties from the analysis. Since these parties are the issue owners, the arguments put forth here may not apply. Given that an increase in the saliency of environmental issues is beneficial for them, they have an incentive to pronounce this issue without the need to learn about the likely consequences. ${ }^{5}$ Finally, we exclude regional, agrarian and other

${ }^{5}$ For a similar approach, see Abou-Chadi (2016) and Spoon, Hobolt and de Vries (2014). 
single-issue parties from the analysis and focus solely on mainstream parties' saliency strategies. ${ }^{6}$ Appendix A lists all parties included in the analysis.

As discussed above, green parties started to politicize environmental issues between the mid-1970s and early 1980s. We therefore focus on the period between 1975 and 2015. In contrast to Meguid (2005), our analysis includes not only the years after a green party emerged but covers the entire time span. Parties can change their saliency strategy towards valence issues in response to various externalities, and they constantly monitor their performance. Indeed, it is crucial for learning processes that the strategy applied can be altered. If parties do not change their strategies, no learning occurs and the hypotheses are falsified. The Comparative Manifesto Project (CMP) provides the data on issue saliency in party manifestos (Volkens et al. 2016). It codes quasisentences within party manifestos for each election and assigns them to a set of pre-defined policy categories. The proportion of quasi-sentences devoted to the environment (per501) is the dependent variable.

\section{Modeling National and Transnational Dependencies}

Empirically testing the support for our hypotheses in a time-series cross-sectional context requires the specification of the dependence structure among parties. To this end, we use our theoretical predictions to specify different spatial lags and estimate spatio-temporal regression models. The spatial lags consist of the sum of the other units' temporally lagged outcome variables, weighted by four connectivity matrices. Based on our hypotheses, we specify four spatial lags using different binary connectivity matrices to link the parties to one another. The connections captured by these matrices allow us to differentiate the linkages among parties along two dimensions: (1) electoral competition and (2) electoral success.

The first two matrices, $W^{F_{W}}$ and $W^{F_{L}}$, connect all parties from the same party family that are not in the same party system and, hence, do not compete electorally. ${ }^{7}$ In accordance with Hypotheses $1 \mathrm{a}$ and $1 \mathrm{~b}$, these matrices capture transnational linkages among parties. $W^{F_{W}}$ links a party to all foreign parties with the same family affiliation that gained votes from the previous to the most recent election in order to capture the effect of successful role models. If parties $i$ and $j$ are connected by this matrix, the cell entrance $W_{i j}^{F_{W}}$ takes a value of 1 , and 0 otherwise. Similarly, the cells of $W^{F_{L}}$ take a value of 1 if parties $i$ and $j$ share a common family affiliation, do not compete electorally, and if party $j$ lost votes between the previous and most recent election.

We specify two additional spatial lags to evaluate Hypothesis 2 about the effect of domestic competition on parties' learning efforts. Similar to the two foreign spatial lags described above, both domestic spatial lags connect parties from the same party family and differentiate between successful $\left(W^{D_{W}}\right)$ and unsuccessful $\left(W^{D_{L}}\right)$ domestic family members. Thus the only difference between the two foreign spatial lags and the two domestic spatial lags is the presence of electoral competition. ${ }^{8}$ Hypothesis 2 predicts that, in contrast to the parties' position-taking strategies, competition impedes learning with respect to saliency strategies. ${ }^{9}$ If a party faces no competitors from the same party family in a given electoral contest, it cannot adjust its strategy in response to

\footnotetext{
${ }^{6}$ The argument made here about learning might not apply to these parties since their manifestos and their electorate are narrowly centered on specific issues, which makes learning about other issues unnecessary. See Green-Pedersen and Mortensen (2015) for empirical evidence of the responsiveness of mainstream parties to other domestic parties.

${ }^{7}$ The CMP provides a party's family affiliation. The parties in the analysis belong to one of the following families: socialist, social democratic, liberal, Christian democratic, conservative or nationalist.

${ }^{8}$ On average, each party has 0.49 family members within the same party system. To demonstrate that the results are not merely driven by outliers, Appendix B reanalyzes the data by linking parties from the same ideological bloc (i.e., left, center and right), which increases the average number of domestically connected parties in each electoral contest to 1.18 (for a similar approach, see e.g., Böhmelt et al. 2016; Böhmelt et al. 2017; Adams and Somer-Topcu 2009).

${ }^{9}$ For theoretical reasons, the connectivity matrices are not row-standardized. It seems reasonable to expect that exposure plays a crucial role in learning (e.g., Neumayer and Plümper 2012). If the number of successful (or unsuccessful) parties increases, a focal party is more likely to learn from these parties' strategies (Shipan and Volden 2008, 842).
} 
Table 1. Expectations based on alternative diffusion mechanisms

\begin{tabular}{llll}
\hline & Conscious learning & Imitation (emulation) & Independent decision making \\
\hline Foreign & $W^{F_{W}}>0$ & $W^{F_{W}}=W^{F_{L}} \neq 0$ & $W^{F_{W}}=W^{F_{L}}=0$ \\
Domestic & $W^{F_{L}}<0$ & $W^{D_{W}}=W^{D_{L}} \neq 0$ & \\
& $W^{D_{W}}>0$ & & $W^{D_{W}}=W^{D_{L}}=0$ \\
\hline
\end{tabular}

Note: cells shaded in gray illustrate the hypothesized mechanisms. Hypotheses $1 \mathrm{a}$ and $1 \mathrm{~b}$ expect conscious learning at the transnational level while Hypothesis 2 implies spatial independence at the domestic level.

the strategies adopted by domestic family members; thus both domestic spatial lags will be restricted to zero.

Importantly, since the countries in our sample have different electoral cycles and information about the other parties' electoral success becomes available only after an election takes place, we temporally lag the spatial lags (see also Adams and Somer-Topcu 2009; Böhmelt et al. 2016). For the domestic spatial lags, we only consider the performance of family members in the last national election. For the foreign spatial lags, we consider the behavior of foreign family members in the most recent election that took place between the previous and current domestic electoral contest. This lag structure mirrors the assumption that parties monitor the electoral fortunes of foreign family members if the respective electoral contest took place after the most recent and before the current domestic election. In addition to theoretical considerations that lead us to conclude that temporally lagged spatial lags are warranted, this time lag also considerably eases model estimation and interpretation. ${ }^{10}$

\section{Identification of the Diffusion Mechanism}

Similarities in parties' saliency strategies can be the result of different processes. Although our argument is based on the notion that parties consciously learn from one another, it is possible that they simply imitate the behavior of other parties. Alternatively, similarities in party strategies might be caused by identical but independent responses to common exogenous circumstances. While distinguishing between these alternative diffusion mechanisms has proven to be difficult in empirical research (for example, Böhmelt et al. 2016; Butler et al. 2017; Gilardi 2010; Shipan and Volden 2008), our research strategy enables us to derive testable implications from the different processes. Table 1 illustrates that we can explicate distinct expectations regarding the results that allow us to differentiate conscious learning from imitation (or emulation) and independent decision making.

In order to distinguish learning from imitation, it is crucial to differentiate between family members who increased their vote share and those who did not. If similarities in parties' strategy adaptation are simply the consequence of imitation, parties should be equally responsive to the saliency strategies of all family members. By implication, the estimates for both foreign spatial lags as well as the estimated for the domestic spatial lags would be identical. If parties are merely imitating their national competitors or 'riding the wave' by responding to the voters' issue priorities, we would find a positive spatial pattern among domestic parties, irrespective of their electoral performance. Instead, if parties selectively learn from other parties' electoral fortunes, they will adopt the strategies of successful family members or avoid strategies that have been unsuccessful elsewhere. Finally, if parties are not responsive to other parties' saliency strategies, the parameter estimate associated with all four spatial lags should be statistically indistinguishable from zero since the fixed effects included in the model control for similar exogenous circumstances.

\footnotetext{
${ }^{10}$ Specifically, temporally lagging spatial lags addresses the problem of simultaneity bias (e.g., Franzese and Hays 2007; Hays, Kachi and Franzese 2010). Furthermore, this specification does not contain instantaneous feedback effects and higherorder dependencies - unless researchers explicitly incorporate higher-order spatial lags (e.g., Whitten, Williams and Wimpy 2019).
} 
Based on the theoretical discussion above, we can derive distinct testable implications that allow us to assess the empirical support for our hypotheses. At the transnational level, we argue that parties consciously learn from successful foreign family members. Consequently, Hypothesis 1a expects that $W^{F_{W}}>0$ while Hypothesis $1 \mathrm{~b}$ implies that $W^{F_{L}}<0$. Our expectation at the domestic level is that parties are not affected by their competitors' strategies. Accordingly, our expectation with respect to Hypothesis 2 is that $W^{D_{W}}=W^{D_{L}}=0$. The highlighted cells in Table 1 illustrate the hypothesized empirical expectations formulated here.

In sum, and in contrast to previous studies (such as Böhmelt et al. 2016), our research strategy enables us to identify the mechanism underlying the diffusion of party strategies.

\section{Alternative Heuristics and Control Variables}

We also test for alternative heuristics that might explain the parties' strategy choice and their emphasis on environmental issues. Besides the saliency strategies adopted by family members, the electoral success of green parties in other countries might also have a direct impact on a party's emphasis on environmental issues. If green parties receive more votes in other countries, parties can infer from this observation that environmental issues are important enough to the electorate to condition their vote choice. To empirically test this alternative heuristic, we include the average vote share of all foreign green parties lagged by one year (Avg Green $\left.{ }_{n-1}\right)$ in our model. ${ }^{11}$

Furthermore, instead of looking at members of their own party family at the domestic level, parties might simply use the saliency strategy adopted by the current incumbent parties as a heuristic. Since incumbent parties successfully obtained office, imitating their campaign strategies from the previous election can be electorally rewarding. Therefore, our model also accounts for the mean environmental issue emphasis of incumbent parties at the domestic level prior to the last national election (Incumbent $\mathrm{DV}_{t-1}$ ).

In addition to these alternative heuristics, we also include a battery of control variables. In line with the agenda-setting literature, Spoon, Hobolt and de Vries (2014) find that the size of the green issue owner positively affects the likelihood that mainstream parties will also highlight environmental issues. An increase in green parties' support indicates that these parties successfully placed environmental issues on the party system agenda, which forces other parties to respond to 'their' issue (for example, Green-Pedersen and Mortensen 2010; Green-Pedersen and Mortensen 2015). To control for this possibility, we include the temporally lagged vote share of the green parties within a party system $\left(\right.$ VSGreen $\left._{t-1}\right)$.

Yet, saliency-based theories predict the reverse effect since responding to strong green parties would boost the greens' vote at the expense of the other parties (for example, Abou-Chadi 2016; Meguid 2005). In order to address this ambiguity, we add a squared version of the variable (VSGreen $_{t-1}^{2}$ ), which captures a possible curvilinear effect. A non-linear relationship might exist since mainstream parties can change their strategies depending on the relative size of a green challenger. When confronted with weak green parties, mainstream parties may de-emphasize environmental issues in an attempt to reduce the saliency of this issue. If domestic green parties get more successful, however, they can establish the environmental issue on the party system's agenda. Since ignoring the issue becomes riskier for other parties, they must respond to this issue.

We also include the annual growth of the gross domestic product (GDP) one year prior to the election $\left(\mathrm{GDP}_{n-1}\right)$. Economic growth allows parties to emphasize issues others than the economy. If the economic conditions are favorable, parties have more opportunities to focus on other issues, and these issues will be more prominent during the electoral campaign (Spoon, Hobolt and de Vries 2014). The data on annual economic growth comes from the World Bank (2017).

Whether or not a party is part of the (coalition) government at the time of the election might also affect the likelihood that it will emphasize environmental issues (Abou-Chadi 2016; Green-Pedersen

\footnotetext{
${ }^{11}$ Since drafting a manifesto takes time, we include the average vote share of all foreign green parties one year prior to the election (e.g., Spoon and Klüver 2015, 345).
} 
Table 2. Descriptive statistics

\begin{tabular}{lcccc}
\hline & Mean & s.d. & Min & Max \\
\hline$Y$ & 0.042 & 0.036 & 0 & 0.228 \\
$D V_{t-1}$ & 0.041 & 0.036 & 0 & 0.228 \\
$W^{F_{W} y}$ & 0.195 & 0.147 & 0 & 0.719 \\
$W^{F_{L} y}$ & 0.260 & 0.205 & 0 & 0.895 \\
$W^{D_{W}}$ & 0.009 & 0.027 & 0 & 0.243 \\
$W^{D_{L}}$ & 0.010 & 0.026 & 0 & 0.254 \\
VSGreen $_{t-1}$ & 2.258 & 3.302 & 0 & 14.350 \\
AvgGreen $_{n-1}$ & 2.315 & 1.981 & 0 & 11.889 \\
GDP $_{n-1}$ & 2.516 & 2.863 & -7.3 & 1 \\
Incumbent $_{t}$ & 0.355 & 0.479 & 0 & 0.155 \\
Incumbent $_{\mathrm{DV}}$ & 0.036 & 0.029 & 0 & 67.880 \\
VS $_{t-1}$ & 17.456 & 13.567 & 0 & \\
\hline
\end{tabular}

and Mortensen 2010; Spoon, Hobolt, and de Vries 2014). While governing parties have to deliver and are held accountable for policy solutions, opposition parties do not face these limitations. Therefore, they are less restricted by the party system agenda and can channel their attention to issues advantageous to them. We use the ParlGov dataset (Döring and Manow 2015) and include a dummy variable indicating the parties' incumbency status at the time of election $t$ (Incumbent I $_{t}$.

A party's decision to emphasize environmental issues also depends on its previous electoral performance (Abou-Chadi 2016; Spoon, Hobolt and de Vries 2014). We control for this by including a variable that measures the parties' previous vote share $\left(\mathrm{VS}_{t-1}\right)$. Finally, we include a lagged dependent variable $\left(\mathrm{DV}_{t-1}\right)$ in the model to account for temporal autocorrelation as well as party and year fixed effects to control for party-specific effects, common shocks and the saliency of environmental issues among the electorate. Table 2 shows the descriptive statistics for all variables.

\section{Results}

Since the dependent variable - the parties' emphasis on the environment - takes on values in the unit interval, we estimate fractional logit models (Papke and Wooldridge 1996; Papke and Wooldridge 2008). ${ }^{12}$ Table 3 presents the results of three model specifications. The first model includes all possible confounding variables together with the two foreign spatial lags for testing Hypotheses 1a and $1 \mathrm{~b}$ while ignoring the effects of domestic family members. Model 2 includes the spatial lags for competing parties from the same party family at the domestic level without taking transnational linkages into account. Finally, the full model specification includes all four spatial lags together with the possible confounding variables. Each model also features party and year fixed effects to account for unit-specific heterogeneity and common exogenous shocks like the nuclear disasters in Chernobyl (1986) and Fukushima (2011).

\section{Coefficient Estimates}

Before turning to the spatial effects, Table 3 shows that the first-order temporal coefficient is insignificant in all model specifications, indicating that there is no path dependency in the parties' emphasis on environmental issues. Rather, at each election, non-issue-owning parties determine how to handle environmental issues without being constrained by their past record. ${ }^{13}$

\footnotetext{
${ }^{12}$ For a similar approach, see Ceron and Curini (2016) and Curini and Martelli (2015). Fractional logit models have the additional advantage that they are able to handle zero-inflation and overdispersion by allowing the dispersion parameter to differ from 1. As the dispersion parameter $\psi$ in Table 3 indicates, the data is zero-inflated and the conditional variance is smaller than the conditional mean, which signifies the appropriateness of our modeling approach.

${ }^{13}$ Moreover, while 10.10 per cent of the observations did not change the environmental issue emphasis between elections, parties reduced the share of environmental quasi-sentences in their manifestos in 44.88 per cent of the cases and increased it
} 
Table 3. Fractional logit model estimates of environmental issues emphasis

\begin{tabular}{|c|c|c|c|}
\hline & \multicolumn{3}{|c|}{ DV: issue emphasis (proportion) } \\
\hline & Model 1 & Model 2 & Model 3 \\
\hline Constant & $\begin{array}{c}-3.080^{\star \star *} \\
(0.555)\end{array}$ & $\begin{array}{c}-2.998^{\star \star \star} \\
(0.556)\end{array}$ & $\begin{array}{c}-3.091^{\star \star \star} \\
(0.556)\end{array}$ \\
\hline $\mathrm{DV}_{t-1}$ & $\begin{array}{c}-1.512 \\
(1.073)\end{array}$ & $\begin{array}{c}-1.516 \\
(1.076)\end{array}$ & $\begin{array}{c}-1.527 \\
(1.077)\end{array}$ \\
\hline$\theta_{1} \mathrm{~W}^{F_{W}} y$ & $\begin{array}{l}0.803^{\star \star \star} \\
(0.298)\end{array}$ & - & $\begin{array}{l}0.809^{\star \star \star} \\
(0.299)\end{array}$ \\
\hline$\theta_{2} \mathrm{~W}^{F_{L} y}$ & $\begin{array}{c}-0.121 \\
(0.244)\end{array}$ & - & $\begin{array}{c}-0.129 \\
(0.246)\end{array}$ \\
\hline$\theta_{3} \mathrm{~W}^{F_{W}} y$ & - & $\begin{array}{c}-0.207 \\
(1.220)\end{array}$ & $\begin{array}{c}0.001 \\
(1.225)\end{array}$ \\
\hline$\theta_{4} \mathrm{~W}^{D_{\llcorner} y}$ & - & $\begin{array}{c}-0.793 \\
(1.278)\end{array}$ & $\begin{array}{c}-0.824 \\
(1.276)\end{array}$ \\
\hline vSGreen $_{t-1}$ & $\begin{array}{c}-0.199^{\star \star \star} \\
(0.043)\end{array}$ & $\begin{array}{l}-0.198^{\star \star \star} \\
(0.044)\end{array}$ & $\begin{array}{c}-0.202^{\star \star \star} \\
(0.043)\end{array}$ \\
\hline VSGreen $_{t-1}^{2}$ & $\begin{array}{l}0.011^{\star \star \star} \\
(0.004)\end{array}$ & $\begin{array}{l}0.011^{\star * \star} \\
(0.004)\end{array}$ & $\begin{array}{l}0.011^{\star \star \star} \\
(0.004)\end{array}$ \\
\hline AvgGreen $_{n-1}$ & $\begin{array}{l}0.327^{\star \star} \\
(0.164)\end{array}$ & $\begin{array}{l}0.362^{\star \star} \\
(0.162)\end{array}$ & $\begin{array}{l}0.332^{\star \star} \\
(0.164)\end{array}$ \\
\hline $\mathrm{GDP}_{n-1}$ & $\begin{array}{c}0.025 \\
(0.020)\end{array}$ & $\begin{array}{c}0.028^{\star} \\
(0.020)\end{array}$ & $\begin{array}{c}0.025 \\
(0.021)\end{array}$ \\
\hline Incumbent $_{t}$ & $\begin{array}{c}-0.047 \\
(0.071)\end{array}$ & $\begin{array}{c}-0.040 \\
(0.071)\end{array}$ & $\begin{array}{c}-0.047 \\
(0.072)\end{array}$ \\
\hline Incumbent $_{\mathrm{DV}_{t-1}}$ & $\begin{array}{l}4.589^{\star \star \star} \\
(1.632)\end{array}$ & $\begin{array}{l}5.104^{\star \star \star} \\
(1.654)\end{array}$ & $\begin{array}{l}4.704^{\star \star \star} \\
(1.663)\end{array}$ \\
\hline $\mathrm{VS}_{t-1}$ & $\begin{array}{c}0.010 \\
(0.007)\end{array}$ & $\begin{array}{c}0.010 \\
(0.007)\end{array}$ & $\begin{array}{c}0.010 \\
(0.007)\end{array}$ \\
\hline $\begin{array}{l}\text { Party and } \\
\text { Year FEs }\end{array}$ & $\checkmark$ & $\checkmark$ & $\checkmark$ \\
\hline$\psi$ & 0.0192 & 0.0193 & 0.0192 \\
\hline Observations & 733 & 733 & 733 \\
\hline RMSE & 0.0233 & 0.0236 & 0.0233 \\
\hline
\end{tabular}

Note: standard errors in parentheses. ${ }^{\star} \mathrm{p}<0.1 ;{ }^{\star \star} \mathrm{p}<0.05 ;{ }^{\star \star \star} \mathrm{p}<0.01$ (two tailed)

We also find empirical evidence for the two alternative heuristics discussed above. First, parties take the success of green parties in other countries as an indication of the voters' demand for green policies. If green parties become more successful abroad, a non-issue-owning party becomes more likely to emphasize environmental issues in its manifesto. Secondly, parties perceive incumbent parties as role models since these parties successfully obtained office. Therefore, saliency strategies adopted by incumbent parties prior to the previous election are likely to be copied by domestic challengers as these strategies have proven to be effective.

Regarding our main theoretical expectations outlined above, the analysis lends support for Hypothesis 1a. The positive and statistically significant spatial coefficient $\theta_{1}$ indicates that parties indeed monitor and react to the behavior of successful family members abroad. Saliency strategies that have been proven useful are likely to be employed by parties with the same family affiliation in other countries. ${ }^{14}$ However, the analysis does not support Hypothesis 1b. Rather than pursuing different strategies than unsuccessful family members abroad, parties simply ignore other parties' negative experiences. Thus, while successful members of the same party family in other polities serve as role models, parties disregard unsuccessful strategies.

in 45.02 per cent. Since the difference between these proportions is statistically insignificant $(\mathrm{p}=0.969)$, we conclude that a reduction in issue emphasis occurs as often as an increase.

${ }^{14}$ Supplementary analyses reveal that the strength of the domestic issue owner does not condition the parties' incentives to learn from successful family members abroad (see Appendix C). Parties facing a strong domestic green party are as likely to learn from their successful family members abroad as parties competing against a weak issue owner. 
Yet simply testing whether regression coefficients are statistically distinct from zero does not constitute an exhaustive test of the suggested learning mechanism. Further implications must be tested in order to distinguish learning from other forms of diffusion.

One testable implication of Hypotheses $1 \mathrm{a}$ and $1 \mathrm{~b}$ is, for example, that the strategies of successful parties should have a different effect than those of unsuccessful parties. Since successful saliency strategies should be more likely to diffuse transnationally, the expectation is that $\theta_{1}>\theta_{2}$, irrespective of whether both coefficients are statistically different from zero. The difference between these spatial coefficients is $\theta_{1}-\theta_{2}=0.938$ with an associated 95 per cent confidence interval of $[0.180 ; 1.696]$, indicating that there is a significant difference between both coefficients and that the null hypothesis $\left(\theta_{1} \leq \theta_{2}\right)$ can be rejected with $\mathrm{p}=0.015$.

Importantly, this finding supports the notion that the diffusion of saliency strategies is not only attributable to mere imitation or independent strategy adaptation. Rather, parties systematically take cues from electorally successful family members in other European countries. Hence, the transfer of saliency strategies from one country to another is the result of strategic decisions taken by the parties (for example, Böhmelt et al. 2016; Dolowitz and Marsh 1996).

Table 3 further shows that the situation at the domestic level is quite different. Both domestic spatial coefficients, $\theta_{3}$ and $\theta_{4}$, are statistically indistinguishable from zero. This finding is in line with Hypothesis 2. If another party within the party system successfully mobilized the electorate on the basis of a valence issue, a focal party cannot learn from this since both parties compete electorally and the party that has successfully used this strategy has an advantage. Hence, the information revealed by the success of competing parties regarding the utility of a saliency strategy does not serve as a heuristic for a focal party. As outlined above, this is because the observed success of a competitor does not allow a party to infer how voters perceive its own competence on that issue, or the competence of all competing parties on any alternative issue.

Hypothesis 2 further expects that, unlike party family members abroad, parties' electoral successes should not matter since parties cannot learn from their domestic competitors. An F-test fails to reject the joint null hypothesis $\theta_{3}=\theta_{4}=0 .(\mathrm{p}=0.780)$ which suggests that, at the domestic level, parties neither learn from nor imitate each others' saliency strategies.

In sum, while parties learn from members of their party family abroad, they do not respond to the saliency strategies employed by domestic members of their own party family. Even more, as parties are unaffected by the strategies of their competitors, our analysis suggests that parties are not 'riding the wave' by converging on the issues that are most important to the electorate. ${ }^{15}$ What distinguishes domestic and foreign party family members is the fact that parties compete for votes at the domestic level. In line with saliency-based theories, competition impedes learning among parties. If a domestic competitor successfully emphasizes a specific issue, the other parties in the same party system cannot easily increase their vote share by adopting the same strategy. As a result, domestic competitors cannot serve as role models.

\section{Average Marginal Short-Term Effects}

To meaningfully interpret these estimates, we calculate the average marginal effects (AME) of the spatial short-term effects for each spatial lag. ${ }^{16}$ Short-term effects are computed by multiplying the spatial coefficient by a unit's number of connections. ${ }^{17}$ They indicate the instantaneous

\footnotetext{
${ }^{15}$ Appendix D provides an empirical assessment of the riding the wave hypothesis.

${ }^{16}$ More precisely, two obstacles complicate the substantive interpretation. First, due to the estimation of a fractional logit model, the link function maps the systematic component to the unit interval and the estimated coefficients only display the relative proportion ratios for a unit increase in the associated predictor variable, holding everything else constant. Secondly, since the connectivity matrices are not row-standardized, the spatial coefficients cannot be interpreted directly because their effect for each unit depends on the number of connections it has. The unequal number of links impedes a comparison of the effect size among the different units.

${ }^{17}$ The average number of connections per observation is 4.53 for $W^{F_{W}}, 5.86$ for $W^{F_{L}}, 0.23$ for $W^{D_{W}}$, and 0.26 for $W^{D_{L}}$.
} 


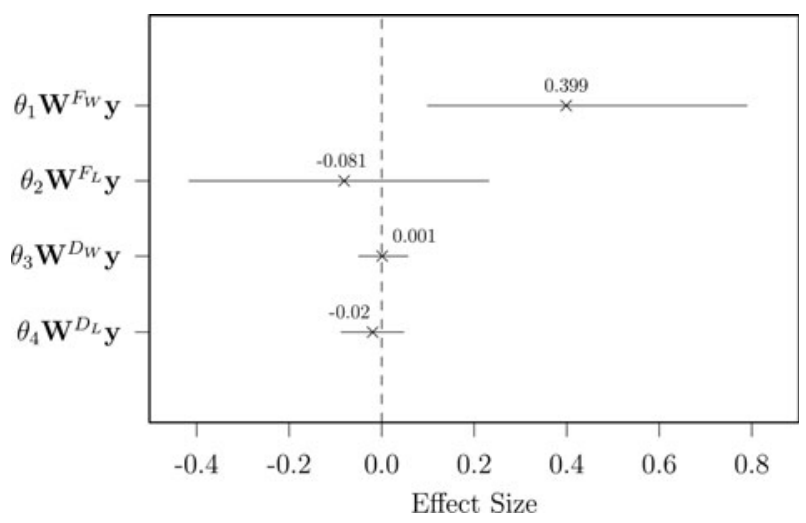

Figure 1. Average Marginal Effects of the Spatial Short-Term Effects. The horizontal bars indicate the simulated 95 per cent confidence interval

impact - that is, the direct effect before any feedback occurs - of the spatial lags on the outcome variable for each unit, taking into account the differences in the number of connections (Plümper and Neumayer 2010). The AMEs of these spatial short-term effects are obtained by first calculating the spatial short-term effects for each unit. Subsequently, we compute the marginal effects of the obtained vector of individual spatial short-term effects given the other covariate values observed in the data and take the average. Figure 1 illustrates these quantities together with simulated uncertainty estimates. ${ }^{18}$

The interpretation of these AMEs is straightforward. All else equal, a one-unit increase in the spatial lag $W^{F_{W}} y$ increases the share of quasi-sentences dedicated to environmental issues within a focal party's manifesto on average by 39.90 per cent [9.91 per cent; 78.94 per cent]. At first sight, this number appears to be surprisingly high. However, when considering the variable's descriptive statistics and the substantive implications of a unit increase, it becomes clear that this situation is very unlikely to happen. A one-unit increase would mean that, for example, one party family member who increased its vote share in the last election increased the share of environmental quasi-sentences within the manifesto from 0 per cent to 100 per cent.

Of course, there are more realistic scenarios that facilitate the interpretation. Consider a party with four successful family members abroad, which is the median number of foreign successful family members in the data. Each of these parties has increased the share of quasi-sentences on environmental issues in their manifestos from one standard deviation below the mean (0.58 per cent) to one standard deviation above the mean (7.78 per cent). Based on the AME, this change in the other parties' issue emphasis leads to an expected increase in the share of environmental quasi-sentences within the focal party's manifesto of 11.50 per cent [ 2.86 per cent; 22.75 per cent], ceteris paribus.

It may be the case that the low number of domestic family members in the party system (each party competes against 0.49 domestic family members, on average) gives too much weight to outlier electoral contexts. As a robustness check, we changed the specification of our connectivity matrices. Instead of their family affiliation, the new matrices connect parties based on their ideological bloc membership. We follow Adams and Somer-Topcu $(2009,834)$ and classify communist and social democratic parties as 'left', liberals as 'centrist', and conservative, Christian democratic and nationalist parties as 'right'. ${ }^{19}$ Doing so increases the average number of

\footnotetext{
${ }^{18}$ We simulate coefficients based on 10,000 random draws from a multivariate normal distribution where the mean vector consists of the coefficient estimates obtained from Model 3 and the corresponding variances come from the estimated variance-covariance matrix.

${ }^{19}$ Recall that in our analysis, we omit green parties as well as regional, agrarian and other small single-issue party families.
} 
neighbors to 1.18. We present the results of these models in Section B of the Appendix. The analysis confirms that the substantive inferences presented above also hold if we assume that parties are connected by their bloc membership rather than their family affiliation.

These results provide strong evidence in favor of transnational dependencies among parties' saliency strategies. While parties learn from their successful family members in foreign polities about when it is beneficial to pronounce valence issues, they are not affected by the strategies adopted by unsuccessful family members abroad. The significant difference between the two foreign spatial lags indicates that conscious learning is responsible for the transnational diffusion of saliency strategies. At the same time, domestic competition impedes learning. As we have argued above, this finding is in line with saliency-based theories of party competition. Enhancing the saliency of an issue benefits the party that voters perceive to be the most competent in the respective policy area. Consequently, parties cannot simply copy successful strategies from their competitors, as this would increase the issue saliency and eventually their competitors' vote share.

\section{Simulation Study: Transnational Spillover Effects}

That is to say, not all domestic parties are irrelevant for the selection of saliency strategies. As predicted by saliency-based theories, Table 3 shows that the strength of the domestic issue owner crucially affects the likelihood that other parties will emphasize the valence issue. In accordance with the findings presented by Abou-Chadi (2016), the negative and statistically significant coefficient of electoral support for an issue owner indicates that non-green parties de-emphasize environmental issues when confronted with strong issue owners. ${ }^{20}$ Moreover, the statistically significant quadratic term suggests that the relationship between green parties' support and the other domestic parties' emphasis on environmental issues is non-linear and has a minimum within the empirical range of the data (at an issue owner's vote share of 9.353 per cent). While parties try to de-emphasize and ignore environmental issues when confronted with a weak issue owner, the analysis reveals a diminishing effect of the green parties' strength on the other parties' emphasis on the valence issue. ${ }^{21}$

Importantly, due to the spatial dependence, green issue owners indirectly affect non-issue owners in other party systems as well. Since they induce domestic competitors to de-emphasize environmental issues in their manifestos, foreign family members copying these strategies are also affected by the green parties' electoral support in these countries. Of course, the possibility that green parties will indirectly induce foreign parties to downplay environmental issues depends on the electoral success of the domestic competitor. As discussed above, whether a party serves as a role model for other parties' electoral strategies in foreign polities depends on the party's electoral performance. Since parties learn selectively from successful foreign family members, the possibility of a spillover effect depends not only on the level of support for a green party but also on the electoral successes of its competitors. A simulation exercise based on Model 3 in Table 3 helps to quantify these spillover effects. ${ }^{22}$

To illustrate these transnational spillover effects of the strength of a domestic issue owner, take the Swedish Riksdag election in 2010 as an example. In the general election in 2006, the Swedish Green Party (MP) received 5.24 per cent of the votes, which is more than twice the average previous vote share of green parties in the sample (see Table 2). Hence, the Swedish parties were already confronted with a comparatively strong issue owner. Despite this, the conservative

\footnotetext{
${ }^{20}$ Note that the model includes spatial and temporal dependencies and the estimated effects of all covariates only provide information about the pre-dynamic effects (see also Hays, Kachi and Franzese 2010).

${ }^{21}$ See Appendix E for a more detailed investigation of the non-linear effect of the domestic green parties' vote share on its competitors.

${ }^{22}$ Again, the results are based on 10,000 random draws from a multivariate normal distribution, which takes the parameters obtained from Model 3 as inputs.
} 


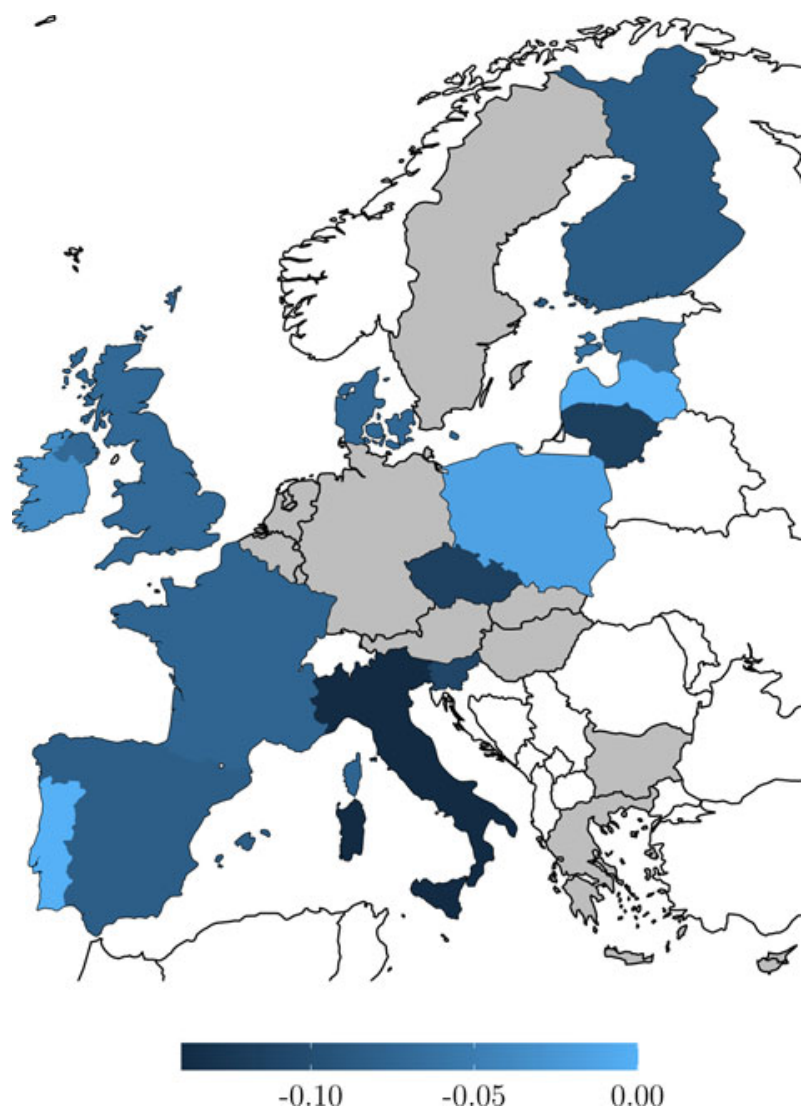

Figure 2. Simulated transnational spillover effects from a change in the Swedish Green Party's previous vote share in 2010 on conservative parties

Moderate Party (M), the only successful party in our dataset in that election as measured by the change in vote share, devoted 10.18 per cent of its manifesto to the environment. If the Green Party's vote share in 2006 was twice as high, our model predicts that the Moderate Party reduces the amount of quasi-sentences concerning the environment to 6.37 per cent [ 2.92 per cent; 10.62 per cent].

Since the Moderate Party was able to increase its vote share in 2010 as compared to the election in 2006, our theory suggests that it served as a role model for conservative parties in other countries. By changing the observed issue emphasis for the Moderate Party to the median predicted share of 7 per cent, we can simulate the transnational spillover effects caused by changes in the electoral success of the Swedish issue owner in the 2010 general election. Figure 2 illustrates the predicted change in environmental issue emphasis of conservative parties in other countries; the colors indicate the magnitude of the change. Gray shaded countries depict polities that are part of our sample, but no conservative party competed in the most recent election after the Swedish general election in September $2010 .^{23}$

As Figure 2 shows, our simulation study predicts that Silvio Berlusconi's People of Freedom (PdL) in Italy would have reduced its emphasis on the environment in the 2013 general election

\footnotetext{
${ }^{23}$ Note that in the general elections in Spain (2011) and France (2012), two conservative parties participated in the election. To ease the visual presentation of the results, Figure 2 depicts the average change in the conservative parties' issue emphasis per country.
} 
by -0.14 percentage points, a reduction of about 2.25 per cent. Similarly, while the Slovenian Democratic Party (SDS) dedicated 6.85 per cent of its manifesto for the 2011 general election to the environment, the increase in the electoral strength of the Swedish Green Party would reduce this share by -0.11 percentage points, or 1.58 per cent, despite the fact that these parties are not directly connected. Therefore, the predicted reduction in environmental issue emphasis for the Swedish Moderate Party, which was caused by changes in the domestic issue owner's electoral support, affects the saliency strategies of conservative parties in other European countries.

Although the size of these spillover effects might appear to be negligible at first, their substantive importance becomes more obvious once we compare them to the overall distribution of environmental issue emphasis in our sample. On average, each party in our sample dedicates only about 4.18 per cent of its manifesto to environmental issues. Hence, the reduction reported in our simulation, despite its seemingly small magnitude, is of substantive importance.

In addition, the implications of these transnational spillover effects are highly relevant. These simulations illustrate a non-trivial dependence structure among European party systems that even goes beyond the direct impact of transnationally connected parties. Domestic pressures arising from political competition within a single party system can indirectly affect parties in other party systems even if they do not directly interact at all. Since parties use the electoral performance of foreign family members as a heuristic to systematically learn about successful saliency strategies, domestic circumstances within these foreign party systems can spill over to other party systems. These results demonstrate how electoral support for the Swedish Green Party, for example, affects the behavior of several conservative parties, although these foreign parties are not directly connected to the domestic issue owner in Sweden.

\section{Conclusion}

How do parties decide when to campaign on valence issues given a high degree of uncertainty? So far, the scholarly literature has focused on characteristics of the party and the domestic party system to explain why parties decide to talk about valence issues in their manifestos. By following the proposition that parties strategically draft their manifestos in order to increase their vote share (for example, Laver and Garry 2000), the present work adds to this literature by illuminating both direct and indirect transnational dependencies in parties' saliency strategies. The explanation provided here is based on conscious learning as a mechanism for parties to mitigate uncertainty and for the diffusion of electoral strategies across national borders.

The results can be summarized in three key points. First, parties dynamically adapt their strategies to the specific context of an electoral campaign. Instead of sticking to their previous strategy, parties manipulate the way they emphasize valence issues. Secondly, parties systematically take cues from members of their party family in foreign polities. The analysis provides evidence that conscious learning from successful family members about the most beneficial electoral strategy is the underlying mechanism causing saliency strategies to diffuse transnationally. Finally, at the domestic level, electoral competition hinders learning. Here, the issue owners' electoral support exerts a non-linear effect on mainstream parties' strategy selection. While mainstream parties seek to de-emphasize environmental issues when confronted with a weak issue owner, the effect diminishes once the issue-owning niche party rallies enough support among the electorate.

Our analysis reveals that European party systems are not independent and hermetically sealed systems with no connections to one another. Rather, the parties acting in these systems create transnational linkages to mitigate electoral uncertainty (see also Böhmelt et al. 2016; Böhmelt et al. 2017; Ezrow et al. 2019). They systematically seek information on the other parties' strategies and their electoral performance as a heuristic to determine when it is potentially vote maximizing to emphasize valence issues. Besides the direct impact of role models in foreign party systems, the analysis also identifies spillover effects that indicate non-trivial interdependencies among 
European party systems. Transnational dependencies are not nuisances, but conscious decisions made by strategic actors in a low-information environment.

These insights have important implications for future research. While the present study primarily focuses on the direct impact of conscious learning on foreign parties' strategies in order to establish the existence of transnational dependencies, the spatial spillover effects identified here deserve more scholarly attention. Despite the small magnitude of these effects, they highlight an important feature of European party systems: their interrelatedness. Domestic pressures arising from electoral competition in one country can affect the electoral strategies of other parties and eventually the course of policy making in foreign polities even if these parties are not directly linked.

Moreover, since the specific institutional design defines the boundaries in which party competition takes place, institutional features like the electoral system or a party's organizational structure might affect its ability to learn. Further research on the effects of these institutional features on the parties' learning behavior is needed. Finally, this study focuses on a single issue dimension. To further validate these findings, future research should pay closer attention to the multidimensional nature of electoral strategies and investigate transnational learning in the context of multiple issue dimensions.

Supplementary material. Online appendices are available at https://doi.org/10.1017/S0007123420000769.

Acknowledgements. An earlier version of this article was presented at the MZES workshop 2017 on 'Party Competition in European Multi-Level Systems' in Mannheim (Germany) and the MPSA conference 2018 in Chicago, IL (USA). We would like to thank our panelists, Thomas Bräuninger, Roni Lehrer, the participants of the 2017 CDSS Political Science Colloquium at the University of Mannheim as well as the anonymous referees and the journal's editor Tobias Böhmelt for valuable input and suggestions.

Data availability statement. Replication data files are available from Harvard Dataverse at: https://doi.org/10.7910/DVN/ QZMPSN.

Financial support. This work was supported by the German Research Foundation - Project-ID 139943784 - SFB 884. Sebastian Juhl also gratefully acknowledges funding from the University of Mannheim's Graduate School of Economic and Social Sciences.

\section{References}

Abou-Chadi T (2016) Niche party success and mainstream party policy shifts: how green and radical right parties differ in their impact. British Journal of Political Science 46(2), 417-436.

Adams J and Somer-Topcu Z (2009) Policy adjustment by parties in response to rival parties' policy shifts: spatial theory and the dynamics of party competition in twenty-five post-war democracies. British Journal of Political Science 39(4), 825-846.

Ansolabehere S and Iyengar S (1994) Riding the wave and claiming ownership over issues: the joint effects of advertising and news coverage in campaigns. The Public Opinion Quarterly 58(3), 335-357.

Berry WD and Baybeck B (2005) Using geographic information systems to study interstate competition. American Political Science Review 99(4), 505-519.

Böhmelt T et al. (2017) Why dominant governing parties are cross-nationally influential. International Studies Quarterly 61 (4), 749-759.

Böhmelt T et al. (2016) Party policy diffusion. American Political Science Review 110(2), 397-410.

Budge I (1994) A new spatial theory of party competition: uncertainty, ideology and policy equilibria viewed comparatively and temporally. British Journal of Political Science 24(4), 443-467.

Budge I (2015) Issue emphases, saliency theory and issue ownership: a historical and conceptual analysis. West European Politics 38(4), 761-777.

Budge I and Farlie D (1983) Explaining and Predicting Elections: Issue Effects and Party Strategies in Twenty-Three Democracies. London: Allen \& Unwin.

Butler DM, et al. (2017) Ideology, learning, and policy diffusion: experimental evidence. American Journal of Political Science 61(1), 37-49.

Carmines EG and Stimson JA (1993) On the evolution of political issues. In Riker WH (ed.), Agenda Formation. Ann Arbor: University of Michigan Press, pp. 151-168.

Carter N (2013) Greening the mainstream: party politics and the environment. Environmental Politics 22(1), 73-94. 
Ceron A and Curini L (2016) e-Campaigning in the 2014 European elections: the emphasis on valence issues in a twodimensional multiparty system. Party Politics 24(2), 105-117.

Curini L and Martelli P (2015) A case of valence competition in elections. Party Politics 21(5), 686-698.

Dolezal M et al. (2014) How parties compete for votes: a test of saliency theory. European Journal of Political Research 53(1), 57-76.

Dolowitz D and Marsh D (1996) Who learns what from whom: a review of the policy transfer literature. Political Studies 44 (2), 343-357.

Dolowitz DP and Marsh D (2000) Learning from abroad: the role of policy transfer in contemporary policy-making. Governance 13(1), 5-23.

Döring H and Manow P (2015) Parliaments and Governments Database (ParlGov): Information on Parties, Elections and Cabinets in Modern Democracies. Stable Version 2015, July 21. Available from http://www.parlgov.org.

Downs A (1957) An Economic Theory of Democracy. New York: Harper and Row.

Elias A, Szöcsik E and Zuber CI (2015) Position, selective emphasis and framing. Party Politics 21(6), 839-850.

Ezrow L et al. (2019) Follow the foreign leader? Why following foreign incumbents is an effective electoral strategy. Party Politics. doi: 10.1177/1354068819884702.

Franzese RJ and Hays JC (2007) Spatial econometric models of cross-sectional interdependence in political science panel and time-series-cross-section data. Political Analysis 15(2), 140-164.

Gilardi F (2010) Who learns from what in policy diffusion processes? American Journal of Political Science 54(3), 650-666.

Graham ER, Shipan CR and Volden C (2013) The diffusion of policy diffusion research in political science. British Journal of Political Science 43(3), 673-701.

Green J (2007) When voters and parties agree: valence issues and party competition. Political Studies 55(3), 629-655.

Green J and Hobolt SB (2008) Owning the issue agenda: party strategies and vote choices in British elections. Electoral Studies 27(3), 460-476.

Green-Pedersen C (2007) The growing importance of issue competition: the changing nature of party competition in Western Europe. Political Studies 55(3), 607-628.

Green-Pedersen C and Mortensen PB (2010) Who sets the agenda and who responds to it in the Danish parliament? A new model of issue competition and agenda-setting. European Journal of Political Research 49(2), 257-281.

Green-Pedersen C and Mortensen PB (2015) Avoidance and engagement: issue competition in multiparty systems. Political Studies 63(4), 747-764.

Hays JC, Kachi A and Franzese RJ (2010) A spatial model incorporating dynamic, endogenous network interdependence: a political science application. Statistical Methodology 7(3), 406-428.

Hix S and Høyland B (2013) Empowerment of the European parliament. Annual Review of Political Science 16(1), 171-189.

Juhl S and Williams LK (2020) "Replication data for: Learning at home and abroad: how competition conditions the diffusion of party strategies. https://doi.org/10.7910/DVN/QZMPSN, Harvard Dataverse, V1

Klüver H and Sagarzazu I (2016) Setting the agenda or responding to voters? Political parties, voters and issue attention. West European Politics 39(2), 380-398.

Laver M and Garry J (2000) Estimating policy positions from political texts. American Journal of Political Science 44(3), 619634.

Laver M and Sergenti E (2012) Party Competition: An Agent-Based Model. Princeton, NJ: Princeton University Press.

Lowe W et al. (2011) Scaling policy preferences from coded political texts. Legislative Studies Quarterly 36(1), $123-155$.

Meguid BM (2005) Competition between unequals: the role of mainstream party strategy in niche party success. American Political Science Review 99(3), 347-359.

Neumayer E and Plümper T (2012) Conditional spatial policy dependence. Comparative Political Studies 45(7), 819-849.

Papke LE and Wooldridge JM (1996) Econometric methods for fractional response variables with an application to 401(k) plan participation rates. Journal of Applied Econometrics 11(6), 619-632.

Papke LE and Wooldridge JM (2008) Panel data methods for fractional response variables with an application to test pass rates. Journal of Econometrics 145(1), 121-133.

Petrocik JR (1996) Issue ownership in presidential elections, with a 1980 case study. American Journal of Political Science 40 (3), 825-850.

Plümper T and Neumayer E (2010) Model specification in the analysis of spatial dependence. European Journal of Political Research 49(3), 418-442.

Riker WH (1996) The Strategy of Rhetoric: Campaigning for the American Constitution. New Haven, CT: Yale University Press.

Robertson D (1976) A Theory of Party Competition. London: John Wiley and Sons.

Shipan CR and Volden C (2008) The mechanisms of policy diffusion. American Journal of Political Science 52(4), 840-857.

Somer-Topcu Z (2009) Timely decisions: the effects of past national elections on party policy change. The Journal of Politics 71(1), 238-248.

Spoon J-J, Hobolt SB and de Vries CE (2014) Going green: explaining issue competition on the environment. European Journal of Political Research 53(2), 363-380. 
Spoon J-J and Klüver H (2015) Voter polarisation and party responsiveness: why parties emphasise divided issues, but remain silent on unified issues. European Journal of Political Research 54(2), 343-362.

Stokes DE (1963) Spatial models of party competition. The American Political Science Review 57(2), 368-377.

Volden C, Ting MM and Carpenter DP (2008) A formal model of learning and policy diffusion. American Political Science Review 102(3), 319-332.

Volkens A et al. (2016) The Manifesto Data Collection. Manifesto Project (MRG/ CMP/ MARPOR). Version 2016b. Berlin: Wissenschaftszentrum Berlin für Sozialforschung (WZB).

Wagner M and Meyer TM (2014) Which issues do parties emphasise? Salience strategies and party organisation in multiparty systems. West European Politics 37(5), 1019-1045.

Whitten GD, Williams LK and Wimpy C (2019) Interpretation: the final spatial frontier. Political Science Research and Methods. doi: 10.1017/psrm.2019.9

Williams LK (2015) It's all relative: spatial positioning of parties and ideological shifts. European Journal of Political Research 54(1), 141-159.

Williams LK and Whitten GD (2015) Don't stand so close to me: spatial contagion effects and party competition. American Journal of Political Science 59(2), 309-325.

World Bank (2017) World Development Indicators. Available from http://data.worldbank.org/data-catalog/world-development-indicators.

Cite this article: Juhl S, Williams LK (2022). Learning at Home and Abroad: How Competition Conditions the Diffusion of Party Strategies. British Journal of Political Science 52, 593-612. https://doi.org/10.1017/S0007123420000769 